Wright State University

CORE Scholar

7-2011

\title{
The effects of Arbuscular Mycorrhizal (AM) Fungal and Garlic Mustard Introductions on native AM Fungal Diversity
}

\author{
Alexander M. Koch \\ Pedro M. Antunes \\ Kathryn Barto \\ Wright State University - Main Campus \\ Don Cipollini \\ Wright State University - Main Campus, don.cipollini@wright.edu \\ Daniel L. Mummey
}

See next page for additional authors

Follow this and additional works at: https://corescholar.libraries.wright.edu/biology

Part of the Biology Commons, Ecology and Evolutionary Biology Commons, Plant Sciences Commons, and the Systems Biology Commons

\section{Repository Citation}

Koch, A. M., Antunes, P. M., Barto, K., Cipollini, D., Mummey, D. L., \& Klironomos, J. N. (2011). The effects of Arbuscular Mycorrhizal (AM) Fungal and Garlic Mustard Introductions on native AM Fungal Diversity. Biological Invasions, 13 (7), 1627-1739.

https://corescholar.libraries.wright.edu/biology/513

This Article is brought to you for free and open access by the Biological Sciences at CORE Scholar. It has been accepted for inclusion in Biological Sciences Faculty Publications by an authorized administrator of CORE Scholar. For more information, please contact library-corescholar@wright.edu. 


\section{Authors}

Alexander M. Koch, Pedro M. Antunes, Kathryn Barto, Don Cipollini, Daniel L. Mummey, and John N. Klironomos 
1 The effects of arbuscular mycorrhizal (AM) fungal and garlic mustard

2 introductions on native AM fungal diversity

3

4

5

6

7

9

Alexander M. Koch ${ }^{14 *}{ }_{v}$, Pedro M. Antunes ${ }^{1 * \dagger}$, E. Kathryn Barto ${ }^{2+}$, Don Cipollini ${ }^{2}$, Daniel L. Mummey ${ }^{3}$ and John N. Klironomos ${ }^{4}$

${ }^{1}$ Department of Integrative Biology, University of Guelph, Guelph, Ontario, N1G 2W1 Canada, ${ }^{2}$ Department of Biological Sciences, Wright State University, Dayton, Ohio 45435 USA, ${ }^{3}$ Microbial Ecology Program, Division of Biological Sciences, The University of Montana, Missoula, Montana 59812 USA, ${ }^{4}$ Department of Biology and physical Geography, 3333 University Way, University of British Columbia (Okanagan Campus), Kelowna, British Columbia, V1V 1V7. Current addresses: ${ }^{\dagger}$ Department of Biology, Algoma University, Sault Ste Marie, Ontario, P6B 2G4 Canada, ${ }^{+}$Institut für Biologie, Freie Universität Berlin, 14195 Berlin Germany

* These authors contributed equally to the work

${ }^{-}$Corresponding author. Postal address: Alexander M. Koch, Dept. of Biology and Physical Geography, Irving K. Barber School of Arts and Sciences, 3333 University Way, University of British Columbia Okanagan, Kelowna, British Columbia, V1V 1V7, Canada.

Email to: akoch13@gmail.com

Telephone: ++ 2508078785

Fax: ++ 2058078005

Keywords: arbuscular mycorrhizal fungi (AMF); Glomus intraradices; inoculation; fungal invasion; community ecology; garlic mustard (Alliaria petiolata); T-RFLP 


\section{Abstract}

27 Introduced, non-native organisms are of global concern, because biological invasions can negatively

28 affect local communities. Arbuscular mycorrhizal (AM) fungal communities have not been well

29 studied in this context. AM fungi are abundant in most soils, forming symbiotic root-associations with

30 many plant species. Commercial AM fungal inocula are increasingly spread worldwide, because of

31 potentially beneficial effects on plant growth. In contrast, some invasive plant species, such as the non-

32 mycorrhizal Alliaria petiolata, can negatively influence AM fungi. In a greenhouse study we examined

33 changes in the structure of a local Canadian AM fungal community in response to inoculation by

34 foreign AM fungi and the manipulated presence/absence of $A$. petiolata. We expected A. petiolata to

35 have a stronger effect on the local AM fungal community than the addition of foreign AM fungal

36 isolates. Molecular analyses indicated that inoculated foreign AM fungi successfully established and

37 decreased molecular diversity of the local AM fungal community in host roots. A. petiolata did not

38 affect molecular diversity, but reduced AM fungal growth in the greenhouse study and in a in vitro

39 assay. Our findings suggest that both introduced plants and exotic AM fungi can have negative impacts

40 on local AM fungi. 


\section{Introduction}

42

43

44

45

46

47

48

49

Invasive species are an increasing phenomenon at a global scale and represent range expansions into non-native habitats. Invasions can lead to changes in community structure, decrease diversity of native species and alter ecosystem functioning (Hooper et al. 2005). Several mechanisms have been proposed to explain why certain species are successful invaders, including release from natural enemies (Agrawal et al. 2005), novel weapons (Callaway and Ridenour 2004), propagule pressure (Lockwood et al. 2005) or specific life-history traits such as high growth rates or resource-use efficiency (Funk and Vitousek 2007). Invaders may also profit from multiple beneficial traits, but often the most important mechanisms of invasiveness remain elusive. Invasive macroorganisms have been relatively well studied, but only recently have we begun making progress in our understanding of microbial invasions (Desprez-Loustau et al. 2007; van der Putten et al. 2007). This is especially true for soil microorganisms, which either directly or through differential feedbacks alter growth and success of native and invasive plants (Callaway et al. 2004; Klironomos 2002). Here we focus on arbuscular mycorrhizal (AM) fungi (phylum Glomeromycota), widespread root symbionts that form associations with the majority of plant species (Smith and Read 2008).

The promise of potentially beneficial effects of AM fungi on plant growth and nutrition has lead to an increase in the use of commercial AM fungal inocula applied as bio-fertilizers (Schwartz et al. 2006). Such inocula often consist of a single AM fungal genotype and are deliberately introduced to locations where they may either not be native or be present at an abundance that would allow coexistence with other native AM fungi. In most instances it remains unclear whether these inoculants successfully establish, and if so, whether they impact the local AM fungal communities. On the other hand, there is also increasing evidence that invasive plant species alter AM fungal communities (Hawkes et al. 2006; Mummey and Rillig 2006), possibly through allelopathic chemicals produced by roots or other tissues (Zhang et al. 2007). Native to Europe, Alliaria petiolata Bieb. Cavara \& Grande (Brassicaceae) is an aggressive biennial invader of forest understories and edge habitats throughout North America. Studies using A. petiolata plant tissues, extracts or soils conditioned by A. petiolata have shown that A. petiolata may be allelopathic to some North American plants and AM fungi (Callaway et al. 2008; Meekins and McCarthy 1999; Prati and Bossdorf 2004; Roberts and Anderson 2001; Vaughn and Berhow 1999). Being non-mycorrhizal, the inhibitory effects of A. petiolata on 
71 ectomycorrhizal and AM fungi may negatively affect mycorrhizal-dependent native plants thereby

72 facilitating the propagation and success of $A$. petiolata (Stinson et al. 2006; Wolfe et al. 2008).

73 Negative effects of introduced organisms on AM fungal diversity may be ecologically important,

74 because changes in AM fungal composition may alter plant diversity and ecosystem productivity

75 (Grime et al. 1987; van der Heijden et al. 1998). AM fungi are ancient plant symbionts (Remy et al.

76 1994) and several AM fungal species, including Glomus intraradices Schenk \& Smith (a species

77 commonly used as a commercial inoculant), have global distributions (Opik et al. 2006).

78 The aim of the present work was to study the interplay of two introduced G. intraradices

79 isolates (and their mixture), the invasive plant A. petiolata, and a native Canadian AM fungal field

80 community naïve to A. petiolata. We chose to study this topic in a controlled greenhouse setting and

81 not in the field, because of the potential risks associated with the release of non-native microbes

82 (Schwartz et al. 2006). Two closely related, yet distinct $G$. intraradices genotypes from Switzerland

83 and Québec were used (Croll et al. 2008; Koch et al. 2004), the latter being widely used for

84 commercial inoculation purposes. Both strains originate from within the native and invaded range of $A$.

85 petiolata, respectively. Based on the findings of Callaway et al. (2008), differentiation in resistance to

86 A. petiolata may not only be present among areas that vary in A. petiolata invasion history, but also

87 among closely related fungal genotypes from within the current range of $A$. petiolata. We also tested

88 whether synergistic effects between these two related strains could be detected, by comparing their

89 mixture to the effects of the two strains as monocultures. We expected that A. petiolata would have

90 more detrimental effects on the diversity and abundance of AM fungi from a native Alliaria-naïve

91 Canadian field community than addition of potentially non-native G. intraradices genotypes, because

92 G. intraradices has previously been documented to frequently occur at this field site (Hart and

93 Klironomos 2002). We also hypothesized that in the presence of Alliaria or its extracts, the growth of

94 the Canadian G. intraradices isolate is more negatively affected than that of its Swiss counterpart.

Materials and Methods 
101 Swiss isolate (B3) originates from an agricultural field near Tänikon (Switzerland) and was obtained

102 from the laboratory of Prof. Ian R. Sanders (University of Lausanne). The Canadian isolate (DAOM

103 197198) originates from an Ash forest near an agricultural field in Pont-Rouge (Quebec) and its

104 genome is currently being sequenced (Martin et al. 2008). We obtained in vitro cultures of this isolate

105 from Premier Tech Biotechnologies (Rivière-du-Loup, Quebec, Canada), who uses this strain as the

106 active ingredient in their commercial inocula Myke ${ }^{\circledR}$-Pro. Both isolates had previously been cultured in

107 axenic root organ cultures (ROCs) on M-medium for over six years (Becard and Fortin 1988) and were

108 clonally re-cultured under standardized conditions (on Petri dishes containing M-Medium and

109 transformed carrot host roots) at least two times at the University of Guelph prior to any experiments.

110 The axenic culture procedures and the isolation history of the Swiss isolate are described in detail in

111 Koch et al. (2004). A. petiolata has not been observed in the native field of the Swiss isolate (T. Anken,

112 personal communication), but this site lies within the native range of $A$. petiolata in Europe. We do not

113 know whether A. petiolata has occurred at the field site where the Canadian isolate originates from, but

114 the invaded A. petiolata range in eastern Canada includes that area.

115

Experiment 1: Greenhouse study

We collected field soil from one location at an old-field meadow, the long-term mycorrhizal

119 research site (LTMRS), on the campus of the University of Guelph in October 2006. Sieved field soil

120 (5 mm mesh width) was stored in an open $50 \mathrm{~L}$ plastic container at room temperature for drying until it

121 was used in the experiment. While G. intraradices has been documented at the LTMRS, to date $A$.

122 petiolata has not been observed there (Hart and Klironomos 2002; Klironomos 2002). A. petiolata

123 frequently occurs in and around Guelph, locally forming dense stands of almost pure monocultures

124 (A.M. Koch, personal observations).

125 Fifty 1-L pots with saucers were used in full factorial design with the following three factors,

126 (i) soil type (sterilized or unsterilized field soil), (ii) A. petiolata (exposed or unexposed), and (iii) $G$.

127 intraradices inoculation type (the Swiss isolate B3, the Canadian isolate DAOM 197198, their mixture,

128 or no inoculation). We prepared inocula for each of the two isolates by pooling and thoroughly

129 homogenizing (with a spoon) eight 15 -week-old ROC plates $(9 \mathrm{~cm}$ diameter, containing M-medium,

130 transformed carrot roots, hyphae and spores). The mixed inoculum consisted of a 1:1 (v:v) mixture of 
131 the two G. intraradices inocula-types. We added $15 \mathrm{ml}$ of inoculum to each pot. The non-mycorrhizal

132 treatments received $15 \mathrm{ml}$ of inoculum also obtained from ROC plates but containing uncolonized

133 carrot roots and no AM fungi. The bottom of each pot consisted of a $200 \mathrm{ml}$ layer of Turface (a

134 montmorillonite clay, Turface Athletics MVP, Profile Products LLC, Buffalo Grove, IL, USA), which

135 was covered with $200 \mathrm{ml}$ of sterilized (steam autoclaved twice at $121{ }^{\circ} \mathrm{C}$ for 60 minutes two weeks

136 before the start of the experiment) or unsterilized field soil. In pots containing A. petiolata, we

137 transplanted single, flowering second-year A. petiolata plants of approximately equal size into this soil

138 layer, with the A. petiolata main root centered in each pot. All A. petiolata plants used were collected

139 in a $5 \mathrm{~m} \mathrm{X} 5 \mathrm{~m}$ patch next to the Greenhouse of the Axelrod Building of the University of Guelph,

140 approximately $1.5 \mathrm{~km}$ away from the LTMRS.

141 On the first day of the experiment (13 May 2007) second year A. petiolata plants of similar

142 size were carefully dug up. Their roots were washed with water to remove all visible soil particles and

143 then placed into pots. G. intraradices inoculum was equally distributed on top of the soil layer and all

144 soils were then covered with $200 \mathrm{ml}$ Turface. One hundred eighty Sorghum vulgare var. sudanense

145 seeds (variety CADAN 99B, Browning Seed Inc., Plainview, TX, USA) were added to each pot and

146 covered by a $2 \mathrm{~cm}$ layer of Turface. We chose $S$. vulgare as host species due to its capacity to establish

147 symbioses with a wide range of AM isolates across the entire Glomeromycota (i.e. the INVAM culture

148 collection, see http://invam.caf.wvu.edu/index.html, representing all major AM taxa). As such

149 mycorrhizal responses to inoculations and/or A. petiolata introduction with this host may underestimate

150 responses in other, more specialized, mycotrophic hosts. Three pots were established for each soil/ $A$.

151 petiolata/AM fungal treatment combination with the following exceptions. We set up four pots for both

152 A. petiolata treatments with unsterilized field soil to which no G. intraradices was added. A. petiolata

153 blend (see below) was accidentally added to one pot containing no A. petiolata plant. This pot was

154 subsequently considered as $+A$. petiolata resulting in four pots of unsterilized field soil with isolate B3

155 and A. petiolata, and only two pots containing sterilized field soil, the isolate $\mathrm{B} 3$ and no A. petiolata.

156 Each pot also received $2 \mathrm{ml}$ of a microbial filtrate (made from a $200 \mathrm{ml}$ vol : $200 \mathrm{ml}$ vol mixture of

157 field soil and soil recovered from the patch where A. petiolata plants and roots were sampled, stirred in

$158800 \mathrm{ml}$ of sterile $\mathrm{H}_{2} \mathrm{O}$, and passed through a $20 \mu \mathrm{m}$ mesh), to minimize differences in non-AM

159 microorganisms. The pots were then randomly arranged on a greenhouse bench and watered three

160 times per week as needed. Temperature in the greenhouse ranged from 23 to $35^{\circ} \mathrm{C}$. Day length was a 
161 minimum of $16 \mathrm{~h}$, supplemented with artificial lights from 6 am to $10 \mathrm{pm}$ when necessary. Because $A$.

162

163

164

165

166

167

168

169

170

171

172

173

174

175

176

177

178

179

180

181

182

183

184

185

186

187

188

189

190 petiolata plants started wilting within two weeks after transplantation, probably due to the transplant shock or natural senescence, we added additional A. petiolata extract to each pot that contained an $A$. petiolata plant on 7 June 2007. For this, we sampled and washed the roots of 30 second-year $A$. petiolata individuals from the same $A$. petiolata population, blended $109 \mathrm{~g}$ fresh weight (fw) $A$. petiolata roots in $1.7 \mathrm{~L}$ water and added $60 \mathrm{ml}$ of the resulting filtrate to each pot. This equates to approximately $3.2 \mathrm{mg}$ A. petiolata tissue equivalents per g soil, which has been estimated to represent expected exposure levels in the field (Callaway et al. 2008).

Plants were harvested on 11 July 2007. For each pot, we counted and excised all Sorghum shoots. Shoots where dried for three days at $70{ }^{\circ} \mathrm{C}$ and weighed. Roots where washed and representative subsamples of about $3 \mathrm{~g}$ fw were collected from each pot and stored in $50 \%$ ethanol and subsequently used for staining and quantification of AM fungal colonization (McGonigle et al. 1990). Root subsamples of about $0.5 \mathrm{~g}$ (fw) were collected into $1.5 \mathrm{ml}$ Eppendorf tubes and immediately placed on ice. These subsamples were then stored at $-80^{\circ} \mathrm{C}$ before being freeze-dried for use in terminal restriction fragment length polymorphism (T-RFLP) analysis. This method enables AM fungal communities to be fingerprinted by analyzing gene polymorphism in a $\sim 380$ bp long section of the large subunit (LSU) rDNA (Mummey and Rillig 2007). Each subsample was individually shredded and a sub-sample of $20 \mathrm{mg}$ weighed into each well of a 96 well block for DNA extraction (NucleoSpin®) 96 Plant, Macherey-Nagel Inc., Bethlehem, PA, USA). A nested PCR protocol was used to amplify DNA from the AM fungi. The fungal community was amplified with LR1/FLR2 primers (Trouvelot et al. 1999; Van Tuinen et al. 1998). The PCR product was then used as template for a second PCR using the 5'-labeled primer pair FLR3-FAM/FLR4-VIC (Applied Biosystems, Foster City, CA, USA) to amplify AM fungi (Gollotte et al. 2004). Both PCRs were comprised of a $30 \mu 1$ reaction mix containing final concentration of 1 x Green GoTaq® Reaction Buffer (Promega, Madison, WI, USA), $1.7 \mathrm{mM} \mathrm{MgCl}_{2}$, $0.13 \mathrm{mM}$ of each dNTP, $0.33 \mathrm{mM}$ of each primer and $1.25 \mathrm{u}$ GoTaq ${ }^{\circledR}$ DNA Polymerase and $1.5 \mu 1$ of template DNA. Products of the first PCR were diluted 1/100 for the second PCR. Both PCRs consisted of an initial denaturation step at $93{ }^{\circ} \mathrm{C}$ for 3 min followed by 35 cycles $\left(93{ }^{\circ} \mathrm{C}\right.$ for $1 \mathrm{~min}, 58^{\circ} \mathrm{C}$ for 1 $\min , 72{ }^{\circ} \mathrm{C}$ for $1 \mathrm{~min}$ ) and a final extension step of $10 \mathrm{~min}$ at $72{ }^{\circ} \mathrm{C}$ in a Mastercycler ${ }^{\circledR e p}$ thermocycler (Eppendorf, Hamburg, Germany). PCR product sizes were verified by gel electrophoresis with a $1 \mathrm{~kb}$ GeneRuler ${ }^{\mathrm{TM}}$ DNA ladder (Fermentas, Burlington, ON, Canada) as a standard. After the second PCR, 
191 products were purified using a QIAquick96® cleanup kit (Qiagen Inc.), before being separately

192 digested with the restriction enzymes AluI and MboI (Invitrogen Inc., Burlington, ON, Canada). The

193 restriction digestion, comprised of a $20 \mu 1$ reaction mix containing $8 \mu 1$ of purified PCR product (total

194 of 60 ng DNA), 1 X REact ${ }^{\circledR} 1$ and 2 buffer (AluI and MboI, respectively) and $2 \mathrm{U}$ of enzyme, was

195 incubated for $4 \mathrm{~h}$ at $37^{\circ} \mathrm{C}$. T-RF sizes in each sample were determined using an ABI 3730 DNA

196 Analyzer with LIZ-500 (Applied Biosystems, Foster City, California, U.S.A.) as the size standard.

Experiment 2: In vitro study

199

We also used ROCs for an in vitro assay (Becard and Fortin 1988; Koch et al. 2004) and

201 manipulated the concentrations of A. petiolata extract in the M-Medium to test responses of the two $G$. intraradices isolates. In the control treatment, no $A$. petiolata extract was added. The $A$. petiolata extract consisted of a 1:1(v:v) mixture of extracts enriched in flavonoids and glucosinolates isolated from first year A. petiolata plants as in Callaway et al. (2008). We used M-medium with five different A. petiolata extract concentrations (AECs), 0, 1.8, 3.6, 5.4 and 7.2 $\mu 1$ A. petiolata extract per ml MMedium, respectively, to test whether different AECs affect growth of AM fungi. The second highest concentration used in our experiment (5.4 $\mu 1 \mathrm{~A}$. petiolata extract per ml M-Medium) corresponded approximately to the concentrations of the combined flavonoid and glucosinolate fractions used by Callaway et al. (2008) that was shown to negatively affect spore germination of AM fungi. For each isolate we inoculated five $25 \mathrm{ml}$ Petri dish plates containing M-Medium with each of the five AECs,

211 for a total of 50 plates. Thus, we had a factorial experimental design with two AM isolates and five

212 AECs. We measured AM hyphal densities of each plate 21, 34, 46, 55, 69, 84 and 99 days after

213 inoculation; lengths of carrot roots were measured 21, 34, 46, 69 and 105 days after inoculation as

214 described previously (Koch et al. 2006; Koch et al. 2004). 
221 Treeflap (Rees et al. 2004), available at http://www.wsc.monash.edu.au/ cwalsh/treeflap.xls, was used

222 to convert fragment sizes to the nearest integer, aligning them with their respective peak heights side

223 by side in two columns. We then developed an R script (R Development Core Team 2007; available

224 upon request from the authors) that standardizes the amount of total fluorescence among sample

225 profiles (Dunbar et al. 2001) and binary codes T-RFLP fingerprints. Presence/absence matrices for

226 each enzyme/primer combination were combined into a single matrix. We used the pooled total

227 number of detected T-RFs per sample as a surrogate of molecular diversity (i.e., T-RF richness,

228 indicative of AM fungal ribotype richness) and compared treatments by analysis of variance (ANOVA,

229 see below). Only T-RF richness was considered in this study and not the height or area of peaks,

230 because the latter parameters may not be indicative of relative abundance of ribotypes. The influence of

231 inoculation and A. petiolata treatments and their interactions on community composition was tested by

232 distance-based redundancy analysis (db-RDA) (Legendre and Anderson 1999). Bray Curtis'

233 coefficients of similarity were first calculated between samples and used to compute principal

234 coordinates in PrCoord 1.0 (part of Canoco version 4.51, Biometris, Wageningen, The Netherlands).

235 All the principal coordinate axes (PCAs) were then exported to Canoco and treated as "species" data.

236 Factors (A. petiolata, AM fungal addition and soil sterilization) were entered as dummy binary

237 variables (one level per column) and their effects tested by using the combined levels of a factor as the

238 explanatory variable in the model while removing the variance explained by the other factors by

239 entering their levels as covariates. The significance of such models was tested with a Monte-Carlo test

240 based on 999 permutations. Where appropriate we used forward selection of environmental variables

241 and conducted Monte-Carlo permutation tests based on 999 permutations. The results of the ordination

242 of the AM fungal community composition, as assessed by PCR-T-RFLP, were displayed as a PCA

243 ordination diagram.

244 Growth traits of plants (total shoot dry weight of hosts, number of host shoots) and AM root

245 colonization traits (percent root lengths colonized by arbuscules, vesicles and hyphae) were analyzed

246 separately by multivariate analysis of variance (MANOVA), followed by univariate ANOVA using

247 fully factorial three-way models and planned contrast analyses (CoA). Additionally, since Callaway et

248 al. (2008) found that $A$. petiolata affects North American AM fungi more negatively than their

249 European counterparts, we compared these two G. intraradices isolates in a separate analysis to

250 investigate whether a similar pattern could be detected. MANOVA and ANOVA results gave overall 
251 qualitatively similar results. For simplicity, we present only significant F-statistics of (M)ANOVAs and

252 CoAs in the result section. To meet the requirements of the statistical tests, variables were transformed

253 if necessary (Zar 1984). In Experiment 2, we used the repeated measures of extraradical hyphal density

254 (H) for each plate to estimate hyphal growth rates (gr) for consecutive measures at days y and $\mathrm{z}$ after

255 the start of the experiment, as

$256 \operatorname{gr}\left(\mathrm{H}_{\mathrm{yz}}\right)=\left[\mathrm{H}_{\mathrm{z}}-\mathrm{H}_{\mathrm{y}}\right] *(\mathrm{z}-\mathrm{y})^{-1}$.

257 From these growth rates, the maximum hyphal gr and time when maximal growth occurred

258 (estimated by the average of days y and $\mathrm{z}$ ) were calculated for each of the 50 replicate plates. Response

259 variables were analyzed by ANOVA and repeated measures ANOVA. Repeated measures ANOVA

260 was performed on the last four dates only, because of non-normality of data (many zero-values) for the

261 previous dates. In both experiments correlations among variables were assessed by Pearson's

262 correlation coefficient $R$ and (M)ANOVAs were performed with the statistical software JMP 5.0 (SAS

263 Institute Inc. Cary, NC, USA).

\section{Results}

Experiment 1: AM fungal community responses assessed by T-RFLP

The detected T-RF richness in roots differed among AM inocula types $\left(F_{3,42}=3.67, P<0.05\right.$,

270 Fig. 1a). The highest T-RF richness was found in field soil, when no G. intraradices inoculum was

271 added. Sterilizing the field soil reduced T-RF detection $\left(F_{1,42}=21.23, P<0.0001\right)$, especially in the

272 absence of $G$. intraradices addition. Removal of T-RFs belonging to G. intraradices profiles

273 (corresponding to the samples from sterile soil) from T-RFLP profiles of G. intraradices inoculated

274 field soil samples eliminated all detected T-RFs in three samples. Overall no direct effect of $A$.

275 petiolata on T-RF richness was observed, except in sterilized field soil without G. intraradices addition

276 where T-RF-richness was lower in presence of $A$. petiolata. However, the T-RF sizes present in these

277 non-inoculated sterile controls were highly variable in quantity and sizes and inconsistent among

278 replicates (data not shown). When analyzing field soil samples only, inoculation by G. intraradices

279 significantly reduced overall T-RF richness $\left(\mathrm{CoA}, F_{1,27}=8.30, P<0.01\right)$, irrespective of presence or

280 absence of $A$. petiolata or inoculum type. Db-RDA of AM fungal community assemblage in field soil 
showed that the inoculation treatments accounted for a significant proportion of the variance $($ Trace $=$

$0.44, F=5.84, P<0.001$, Fig. 1b), whereas the presence of $A$. petiolata did not have a significant effect (Trace $=0.08, F=0.79, P<0.88$ ). The analysis of $G$. intraradices treatments indicates that there was an overlap between soil sterilization treatments (Trace $=0.095, F=1.25, P<0.15$ ), giving further support to the hypothesis that G. intraradices became dominant upon inoculation of field soil (Fig. 1b). In field soil, a significant proportion of the variance was explained by the different $G$. intraradices inocula $($ Trace $=0.17, F$-ratio $=2.26, P<0.05$, Fig. 1b). As in sterilized soils, the two isolates of $G$. intraradices also formed separate clusters in field soil, whereas the samples of the mixture of the two isolates were clustered between the individual isolates (Fig. 1b).

Experiment 1: Fungal and plant growth responses

Our AM fungal inoculation treatments significantly differed $\left(F_{9,102}=6.51, P<0.0001\right.$, Fig. 2$)$.

In sterilized soils, no AM-specific structures (i.e. vesicles and arbuscules) were observed in the roots of control plants that received no addition of $G$. intraradices inoculum (Fig. 2a and b). Overall fungal root colonization was lower in pots where the Canadian isolate was added compared with pots where the

297 Swiss isolate was present either as a pure culture or a mixture (CoA, $\left.F_{3,32}=3.82, P<0.05\right)$. However, inoculation by $G$. intraradices in field soil did not significantly alter root colonization by AM fungi compared to non-inoculated samples ( $\left.\mathrm{CoA}, F_{3,16}=0.31, P=0.81\right)$. A. petiolata negatively affected levels of root colonization by AM fungi $\left(F_{3,32}=3.16, P<0.05\right.$, Fig. 2$)$. When analyzing only the effect

301 of adding the Swiss and the Canadian isolate as pure cultures, A. petiolata significantly reduced fungal growth $\left(F_{3,14}=5.01, P<0.05\right)$. Addition of the Swiss isolate resulted in higher root colonization than inoculation by the Canadian isolate $\left(F_{3,14}=4.88, P<0.05\right)$, and we detected a significant three-way interaction between the two AM fungal isolates, $A$. petiolata and the sterilization of soil $\left(F_{3,14}=3.85, P\right.$ $<0.05$ ). In field soil A. petiolata reduced root colonization of both isolates similarly, whereas in sterilized soils, A. petiolata had a negative effect on growth of only the Canadian isolate. 607.96 and $F_{6,68}=4.51, P<0.001$ in both cases, respectively, Fig. 3). Sterilization of soils almost doubled plant shoot dry weight and tended to increase the number of shoots $\left(F_{2,33}=607.96, P<\right.$ 0.0001, Fig. 3). There was a significant interaction between soil sterilization and AM fungal 
311 inoculation (approximate $F_{6,68}=5.01, P<0.001$, Fig. 3). Adding G. intraradices to sterilized soils

312 significantly reduced plant shoot weight overall relative to controls (no G. intraradices inoculum

313 added; CoA, $F_{1,34}=10.33, P<0.01$ ). In field soil, addition of the isolate mixture resulted in the highest

314 shoot dry weights and number of shoots. This interaction remained significant when the controls (no $G$.

315 intraradices addition) were removed from the analysis $\left(F_{4,48}=2.83, P<0.05\right)$. Neither did we detect a

316 significant effect of $A$. petiolata on host growth $\left(F_{2,33}=0.39, P=0.68\right)$ nor a significant $A$. petiolata

317 interaction with any of the other main factors $(P>0.58$ for all interactions, Fig. 3$)$.

Experiment 2: In vitro study 0.96), but significantly decreased with increasing concentration of $A$. petiolata extract in the growth medium $\left(F_{4,40}=3.81, P<0.01 ;\right.$ Fig. 4 a) $)$ Maximal hyphal growth rates were positively correlated with the final hyphal density $(R=0.74, P<0.0001)$ and the two isolates differed significantly when maximal hyphal growth occurred $\left(F_{1,40}=12.82, P<0.01\right.$; Fig. $\left.4 \mathrm{~b}\right)$. The Canadian isolate had a delayed maximal growth relative to the Swiss isolate, especially at intermediate AECs. However, when no $A$. petiolata extract was added and at high AECs, responses of the two isolates were similar. These trends explained the significant 3-way interaction among measurement date, A. petiolata treatment and isolate in a repeated measures ANOVA on hyphal lengths (approximate $F_{12,120}=1.97, P<0.05$ ). The Swiss isolate had transiently higher hyphal densities than the Canadian isolate after 55 and 69 days of growth,

331 especially at low AECs (data not shown). Final root lengths were not significantly altered by any of the treatments (data not shown) and were negatively correlated with hyphal densities at the last measurement $(R=-0.3020, P<0.05)$.

\section{Discussion}

AM fungal community and host plant responses to inoculation by $G$. intraradices 
341 drastic decrease of detected T-RFs obtained from roots (Fig. 1). Since we also characterized T-RFLP

342 profiles of $G$. intraradices in sterilized substrates, we were able to estimate to which extent the shift in

343 community assemblage was toward the introduced profiles. We found that addition of $G$. intraradices

344 to field soil clearly had a negative effect on native AM diversity. However, due to limitations of the

345 technique (Avis et al. 2006), we cannot conclude that $G$. intraradices outcompeted all native AM

346 fungi. Fungi occurring at low frequency may have not been detected, and some G. intraradices specific

347 T-RFs were also present in the field soil. However, our findings suggest that, irrespective of the

348 identity of the isolate, introduced G. intraradices successfully established and became dominant. This

349 finding is relevant since the Canadian isolate used in our experiments is currently spread worldwide as

350 commercial inoculum. Our inoculum was obviously very infective, demonstrating that some

351 commercial inocula have the potential to establish and (at least temporarily) disrupt the diversity of

352 local AM fungal communities. To assess the impact of introduction of exotic AM fungi to native AM

353 fungal communities we call for long-term studies and AM community surveys of field sites where

354 fungal inoculants have been applied in the past. Potential benefits in plant growth should be weighed

355 with the possibility of irreversible long-term alterations of soil microbial communities when applying

356 non-native inocula. Consistent with our findings, pre-inoculation of plants with two Glomus strains

357 greatly decreased the detected ribotype richness of another native AM fungal community in roots of

358 hosts that were transplanted into field soil, relative to plants that were not pre-inoculated (Mummey et

359 al. 2009). In contrast, inoculation of an agricultural soil with a commercial inoculant containing the

360 Canadian isolate of $G$. intraradices at the rate of application recommended by the supplier did not

361 affect the resident AM fungal community in maize roots (Antunes et al. 2009). These findings suggest

362 that successful establishment of an inoculant may depend on the amount and type of inoculum and/or

363 the diversity and genotypic identities found in the target community. Limited inoculum addition may

364 reduce both the inoculants initial rate of establishment and its subsequent impact on native AM fungi.

365 In a more natural setting (i.e., unmanaged soils) where native AM fungi may already have formed

366 intact hyphal networks and colonized most of the plant roots, additional non-native AM fungi may be

367 less likely to become problematic invaders. Success of AM fungal isolates also depends on the identity

368 of host plants (Ehinger et al. 2009; Klironomos 2003) and other environmental factors such as the local

369 climate, soil properties, or the local AM community composition (Maherali and Klironomos 2007). An

370 AM fungal inoculant could also directly interact with resident genotypes of the same species, since 
371 closely related, but genetically distinct AM fungi can anastomose and exchange genetic information

372 (Croll et al. 2009; Croll and Sanders 2009). Whether or not the addition of an inoculant is beneficial or

373 harmful to its native conspecifics or AM fungal diversity remains to be explored. Our findings

374 highlight that, at least at high inoculum application rates, introduced non-native AM fungi may

375 negatively impact resident AM fungi. Future experiments should also investigate whether repeated

376 inoculant-applications at lower rates would have similar effects.

377 Plant growth was strongly enhanced in sterilized field soil, likely a result of combined effects

378 of nutrient release, or a reduced presence of soil biota or pathogens. Relative to non-inoculated

379 controls, G. intraradices addition decreased host growth in sterilized field soil, possibly by competition

380 for nutrients, similar to the negative correlation between plant and fungal growth observed in

381 Experiment 2. On the other hand, in field soil where a native community was already present,

382 inoculation by G. intraradices increased the number of shoots, possibly by enhancing seed

383 germination, seedling survival (van der Heijden 2004) or protection from root pathogens (Sikes et al.

384 2009, Wehner et al., 2010). Interestingly, we also found that the combined mixture of both $G$.

385 intraradices isolates had different effects on plant growth relative to separate effects of the two

386 isolates, revealing an unexpected intraspecific synergism. This suggests that functional

387 complementarity may not only occur among (Jansa et al. 2008; Maherali and Klironomos 2007), but

388 also within AM fungal species. Thus, environmental factors, genotype identity and diversity within

389 AM species alter host plant performance from antagonistic to beneficial (Koch et al. 2006), possibly

390 due to altered resource uptake or pathogen protection (Johnson et al. 1997; Newsham et al. 1995).

Host plant and AM fungal community responses to $A$. petiolata

Allelochemicals produced by certain invasive plants, including $A$. petiolata, have been 395 reported to limit the growth of native plants (Bais et al. 2003; Dorning and Cipollini 2006; Ridenour 396 and Callaway 2001; Stinson et al. 2006). However, A. petiolata did not significantly alter the growth of 397 host plants in our experiments. Thus AM-inhibitory effects caused by A. petiolata, as evidenced by an 398 overall reduction in levels of AM root colonization and hyphal growth, corroborate previous reports of 399 negative effects of A. petiolata allelochemicals on mycorrhizal fungi (Callaway et al. 2008; Roberts and Anderson 2001; Stinson et al. 2006; Wolfe et al. 2008). Contrary to our hypothesis, A. petiolata did 
401 not significantly affect community composition and richness of local AM fungi found in field soil in

402 our greenhouse study. This suggests that different native AM fungal taxa were affected similarly by $A$.

403 petiolata. Exposure to actively growing first-year rosettes, which are known to vary in chemistry from

404 second year plants, may have different effects. In sterilized substrates A. petiolata altered TRF-

405 composition only of non-mycorrhizal controls, but these effects are likely biologically meaningless

406 resulting from unspecific primer binding, since no AM fungi were visible in these roots. On the other

407 hand A. petiolata had a more negative effect on the growth of the Canadian isolate than on the Swiss

408 isolate in both experiments. Even though we have not tested replicate $G$. intraradices isolates from

409 Europe and North America, these findings support the existence of transcontinental divergence in $A$.

410 petiolata-tolerance as suggested by the findings of Callaway et al. (2008); random effects are unlikely

411 to produce such a predicted pattern. However, in field soil without $G$. intraradices inoculation $A$.

412 petiolata did not entirely suppress AM root colonization by local AM fungi, which could reflect sub-

413 lethal concentrations of allelochemicals, possibly due to microbial degradation of A. petiolata

414 metabolites in field soil (Barto and Cipollini 2009; Gimsing et al. 2007; Gimsing et al. 2006; Tsao et al.

4152000 ) or a certain inherent tolerance of local AM to A. petiolata. The latter interpretation is consistent

416 with findings of two recent studies that analyzed AM communities in host plants from patches that

417 were invaded or uninvaded by A. petiolata. First-year A. petiolata plants did not affect AM fungal T-

418 RF richness within roots of sugar maple seedlings from eight sites in Ohio and Massachusetts, but

419 altered the AM fungal community composition in half of the sites monitored (Barto E. K., unpublished

420 data). Similarly, A. petiolata did not alter levels of AM root colonization of three plant species at one

421 site in Pennsylvania and only affected AM communities in the roots of one plant species (Burke 2008).

423 The potential role of soil microbes in co-evolutionary outcomes for invasive species

In our short-term study, introducing non-native AM isolates to a native AM community had

426 much more drastic effects than introducing A. petiolata. The introduced G. intraradices isolates

427 became dominant, implying that drastic frequency shifts had occurred within the native AM fungal

428 community inside host plant roots. Undoubtedly, long-term field studies are required to test whether a

429 successful short-term establishment is also indicative of persistence. In light of our results, however, 
current practices of commercial AM fungal inocula applications to field sites means accepting the risks of potentially irreversible microbial invasions of unknown consequences (Schwartz et al. 2006). Reported negative effects of $A$. petiolata on AM fungi and AM-dependent plants may enhance the success of A. petiolata in North America at some invaded sites (Callaway et al. 2008; Stinson et al. 2006). Thus, invasive species act as a new selective force altering above- and belowground native populations and communities in invaded sites. Selection for more A. petiolata-tolerant soil microbes, decomposers of A. petiolata phytochemicals, native natural enemies, or less toxic A. petiolata may counteract the success of and spread of A. petiolata over time (Burke 2008; Enright and Cipollini 2007; Lankau et al. 2009). The numerous on-going biological invasions around the globe offer possibilities to study ongoing co-evolutionary dynamics of native communities. An analysis of invasions by various organisms showed that many invasions become regulated at some point in time (Arim et al. 2006). This does not lessen the negative impacts that invaders cause locally, but rather suggests that there are mechanisms that regulate species in their new habitats. Invasive species find themselves in a novel environment, facing new selective pressures, which can result in evolutionary changes or niche shifts (Broennimann et al. 2007; Lee 2002; Schlaepfer et al. 2005). However, for many soil microbes, and AM fungi in particular, such investigations have rarely been undertaken. Even though these organisms escape our direct sight, they do have important effects on ecosystem function (Rillig 2004) and should not be ignored.

\section{Acknowledgements}

We thank Michael Mucci and Lindsay Wilson for technical assistance. Isabelle Meusnier and the Biodiversity Institute of Ontario helped us with the T-RFLP analysis. A.M.K. was supported by fellowships from the Swiss National Science Foundation (PBLAA-114210 and PAOOA-119519) and the Roche Research Foundation. D.L.M. was supported by grants from National Science Foundation Ecology (0515904) and United States Department of Agriculture - Cooperative State Research, Education, and Extension Service (2005-35320-16267). We also thank the Natural Sciences and Engineering Research Council of Canada for financial support. 
Agrawal AA, Kotanen PM, Mitchell CE, Power AG, Godsoe W, Klironomos J (2005) Enemy release? An experiment with congeneric plant pairs and diverse above- and belowground enemies. Ecol 86:2979-2989

Antunes PM, Koch AM, Dunfield KE, Hart MM, Downing A, Rillig MC, Klironomos JN (2009) Influence of commercial inoculation with Glomus intraradices on the structure and functioning of an AM fungal community from an agricultural site. Plant Soil 317:257-266

Arim M, Abades SR, Neill PE, Lima M, Marquet PA (2006) Spread dynamics of invasive species. Proc Natl Acad Sci USA 103:374-378

Avis PG, Dickie IA, Mueller GM (2006) A 'dirty' business: testing the limitations of terminal restriction fragment length polymorphism (TRFLP) analysis of soil fungi. Mol Ecol 15:873-882 Bais HP, Vepachedu R, Gilroy S, Callaway RM, Vivanco JM (2003) Allelopathy and exotic plant invasion: From molecules and genes to species interactions. Science 301:1377-1380 Barto EK, Cipollini D (2009) Half-lives and field soil concentrations of Alliaria petiolata secondary metabolites. Chemosphere 76:71-75

Becard G, Fortin JA (1988) Early events of vesicular arbuscular mycorrhiza formation on Ri T-DNA transformed roots. New Phytol 108:211-218

Broennimann O, Treier UA, Muller-Scharer H, Thuiller W, Peterson AT, Guisan A (2007) Evidence of climatic niche shift during biological invasion. Ecol Lett 10:701-709

Burke DJ (2008) Effects of Alliaria petiolata (garlic mustard; Brassicaceae) on mycorrhizal colonization and community structure in three herbaceous plants in a mixed deciduous forest. Am J Bot 95:1416-1425

Callaway RM, Cipollini D, Barto K, Thelen GC, Hallett SG, Prati D, Stinson K, Klironomos J (2008) Novel weapons: Invasive plant suppresses fungal mutualists in America but not in its native Europe. Ecol 89:1043-1055

Callaway RM, Ridenour WM (2004) Novel weapons: invasive success and the evolution of increased competitive ability. Front Ecol Environ 2:436-443

Callaway RM, Thelen GC, Rodriguez A, Holben WE (2004) Soil biota and exotic plant invasion. Nature 427:731-733

Croll D, Giovannetti M, Koch AM, Sbrana C, Ehinger M, Lammers PJ, Sanders IR (2009) Nonself vegetative fusion and genetic exchange in the arbuscular mycorrhizal fungus Glomus intraradices. New Phytol 181:924-937

Croll D, Sanders IR (2009) Recombination in Glomus intraradices, a supposed ancient asexual arbuscular mycorrhizal fungus. BMC Evolutionary Biology 9

Croll D, Wille L, Gamper HA, Mathimaran N, Lammers PJ, Corradi N, Sanders IR (2008) Genetic diversity and host plant preferences revealed by simple sequence repeat and mitochondrial markers in a population of the arbuscular mycorrhizal fungus Glomus intraradices. New Phytol 178:672-687 Desprez-Loustau M-L, Robin C, Buée M, Courtecuisse R, Garbaye J, Suffert F, Sache I, Rizzo DM (2007) The fungal dimension of biological invasions. Trends Ecol Evol 22:472-480 Dorning M, Cipollini D (2006) Leaf and root extracts of the invasive shrub, Lonicera maackii, inhibit seed germination of three herbs with no autotoxic effects. Plant Ecol 184:287-296 Dunbar J, Ticknor LO, Kuske CR (2001) Phylogenetic specificity and reproducibility and new method for analysis of terminal restriction fragment profiles of $16 \mathrm{~S}$ rRNA genes from bacterial communities. Appl Environ Microbiol 67:190-197 Ehinger M, Koch AM, Sanders IR (2009) Changes in arbuscular mycorrhizal fungal phenotypes and genotypes in response to plant species identity and phosphorus concentration. New Phytol 184:412-423 Enright SM, Cipollini D (2007) Infection by powdery mildew Erysiphe cruciferarum (Erysiphaceae) strongly affects growth and fitness of Alliaria petiolata (Brassicaceae). Am J Bot 94:1813-1820 Funk JL, Vitousek PM (2007) Resource-use efficiency and plant invasion in low-resource systems. Nature 446:1079-1081 Gimsing AL, Sorensen JC, Strobel BW, Hansen HCB (2007) Adsorption of glucosinolates to metal oxides, clay minerals and humic acid. Appl Clay Sci 35:212-217 Gimsing AL, Sorensen JC, Tovgaard L, Jorgensen AMF, Hansen HCB (2006) Degradation kinetics of glucosinolates in soil. Environ Tox Chem 25:2038-2044 
Gollotte A, van Tuinen D, Atkinson D (2004) Diversity of arbuscular mycorrhizal fungi colonising roots of the grass species Agrostis capillaris and Lolium perenne in a field experiment. Mycorrhiza 14:111-117

Grime JP, Mackey JML, Hillier SH, Read DJ (1987) Floristic diversity in a model system using experimental microcosms. Nature 328:420-422

Hart MM, Klironomos JN (2002) Diversity of arbuscular mycorrhizal fungi and ecosystem functioning. In: van der Heijden, M. G. A. and Sanders, I. R. (eds.), Mycorrhizal Ecology. Springer, pp. 225-242 Hawkes CV, Belnap J, D'Antonio C, Firestone MK (2006) Arbuscular mycorrhizal assemblages in native plant roots change in the presence of invasive exotic grasses. Plant and Soil 281:369-380 Hooper DU, Chapin FS, Ewel JJ, Hector A, Inchausti P, Lavorel S, Lawton JH, Lodge DM, Loreau M, Naeem S, Schmid B, Setala H, Symstad AJ, Vandermeer J, Wardle DA (2005) Effects of biodiversity on ecosystem functioning: A consensus of current knowledge. Ecol Monogr 75:3-35

Jansa J, Smith FA, Smith SE (2008) Are there benefits of simultaneous root colonization by different arbuscular mycorrhizal fungi? New Phytol 177:779-789

Johnson NC, Graham JH, Smith FA (1997) Functioning of mycorrhizal associations along the mutualism-parasitism continuum. New Phytol 135:575-586

Klironomos JN (2002) Feedback with soil biota contributes to plant rarity and invasiveness in communities. Nature 417:67-70

Klironomos JN (2003) Variation in plant response to native and exotic arbuscular mycorrhizal fungi. Ecol 84:2292-2301

Koch AM, Croll D, Sanders IR (2006) Genetic variability in a population of arbuscular mycorrhizal fungi causes variation in plant growth. Ecol Lett 9:103-110

Koch AM, Kuhn G, Fontanillas P, Fumagalli L, Goudet J, Sanders IR (2004) High genetic variability and low local diversity in a population of arbuscular mycorrhizal fungi. Proc Natl Acad Sci USA 101:2369-2374

Lankau RA, Nuzzo V, Spyreas G, Davis AS (2009) Evolutionary limits ameliorate the negative impact of an invasive plant. Proc Natl Acad Sci USA 109:15362-15367

Lee CE (2002) Evolutionary genetics of invasive species. Trends Ecol Evol 17:386-391

Legendre P, Anderson MJ (1999) Distance-based redundancy analysis: Testing multispecies responses in multifactorial ecological experiments. Ecol Monogr 69:1-24

Lockwood JL, Cassey P, Blackburn T (2005) The role of propagule pressure in explaining species invasions. Trends Ecol Evol 20:223-228

Maherali H, Klironomos JN (2007) Influence of phylogeny on fungal community assembly and ecosystem functioning. Science 316:1746-1748

Martin F, Gianinazzi-Pearson V, Hijri M, Lammers P, Requena N, Sanders IR, Shachar-Hill Y, Shapiro H, Tuskan GA, Young JPW (2008) The long hard road to a completed Glomus intraradices genome. New Phytol 180:747-750

McGonigle TP, Miller MH, Evans DG, Fairchild GL, Swan JA (1990) A new method which gives an objective-measure of colonization of roots by vesicular arbuscular mycorrhizal fungi. New Phytol 115:495-501

Meekins JF, McCarthy BC (1999) Competitive ability of Alliaria petiolata (garlic mustard, Brassicaceae), an invasive, nonindigenous forest herb. Int J Plant Sci 160:743-752

Mummey DL, Antunes PM, Rillig MC (2009) Arbuscular mycorrhizal fungi pre-inoculant identity determines community composition in roots. Soil Biol Biochem:1173-1179

Mummey DL, Rillig MC (2006) The invasive plant species Centaurea maculosa alters arbuscular mycorrhizal fungal communities in the field. Plant Soil 288:81-90

Mummey DL, Rillig MC (2007) Evaluation of LSU rRNA-gene PCR primers for analysis of arbuscular mycorrhizal fungal communities via terminal restriction fragment length polymorphism analysis. J Microbiol Methods 70:200-204

Newsham KK, Fitter AH, Watkinson AR (1995) Multi-functionality and biodiversity in arbuscular mycorrhizas. Trends Ecol Evol 10:407-411

Opik M, Moora M, Liira J, Zobel M (2006) Composition of root-colonizing arbuscular mycorrhizal fungal communities in different ecosystems around the globe. J Ecol 94:778-790

Prati D, Bossdorf O (2004) Allelopathic inhibition of germination by Alliaria petiolata (Brassicaceae). Am J Bot 91:285-288

Rees GN, Baldwin DS, Watson GO, Perryman S, Nielsen DL (2004) Ordination and significance testing of microbial community composition derived from terminal restriction fragment length polymorphisms: application of multivariate statistics. Antonie Van Leewenhoek Int J Gen Mol Biol 86:339-347 
Remy W, Taylor TN, Hass H, Kerp H (1994) Four-hundred-million-year-old vesicular-arbuscular mycorrhizae. Proc Natl Acad Sci USA 91:11841-11843

Ridenour WM, Callaway RM (2001) The relative importance of allelopathy in interference: the effects of an invasive weed on a native bunchgrass. Oecologia 126:444-450

Rillig MC (2004) Arbuscular mycorrhizae and terrestrial ecosystem processes. Ecol Lett 7:740-754 Roberts KJ, Anderson RC (2001) Effect of garlic mustard Alliaria petiolata (Beib. Cavara \& Grande) extracts on plants and arbuscular mycorrhizal (AM) fungi. Am Midland Nat 146:146-152

Schlaepfer MA, Sherman PW, Blossey B, Runge MC (2005) Introduced species as evolutionary traps. Ecol Lett 8:241-246

Schwartz MW, Hoeksema JD, Gehring CA, Johnson NC, Klironomos JN, Abbott LK, Pringle A (2006) The promise and the potential consequences of the global transport of mycorrhizal fungal inoculum. Ecol Lett 9:501-515

Sikes BA, Cottenie K, Klironomos JN (2009) Plant and fungal identity determines pathogen protection of plant roots by arbuscular mycorrhizas. J Ecol 97:1274-1280

Smith SE, Read DJ (2008) Mycorrhizal Symbiosis. Academic Press, London, U.K. Stinson KA, Campbell SA, Powell JR, Wolfe BE, Callaway RM, Thelen GC, Hallett SG, Prati D, Klironomos JN (2006) Invasive plant suppresses the growth of native tree seedlings by disrupting belowground mutualisms. PLoS Biology 4:727-731

Trouvelot S, van Tuinen D, Hijri M, Gianinazzi-Pearson V (1999) Visualization of ribosomal DNA loci in spore interphasic nuclei of glomalean fungi by fluorescence in situ hyhridization. Mycorrhiza 8:203-206

Tsao R, Yu Q, Friesen I, Potter J, Chiba M (2000) Factors affecting the dissolution and degradation of oriental mustard-derived sinigrin and allyl isothiocyanate in aqueous media. J Agri Food Chem 48:1898-1902

van der Heijden MGA (2004) Arbuscular mycorrhizal fungi as support systems for seedling establishment in grassland. Ecol Lett 7:293-303

van der Heijden MGA, Klironomos JN, Ursic M, Moutoglis P, Streitwolf-Engel R, Boller T, Wiemken A, Sanders IR (1998) Mycorrhizal fungal diversity determines plant biodiversity, ecosystem variability and productivity. Nature 396:69-72

van der Putten WH, Klironomos JN, Wardle DA (2007) Microbial ecology of biological invasions. ISME J 1:28-37

van Tuinen D, Jacquot E, Zhao B, Gollotte A, Gianinazzi-Pearson V (1998) Characterization of root colonization profiles by a microcosm community of arbuscular mycorrhizal fungi using 25S rDNAtargeted nested PCR. Mol Ecol 7:879-887

Vaughn SF, Berhow MA (1999) Allelochemicals isolated from tissues of the invasive weed garlic mustard (Alliaria petiolata). J Chem Ecol 25:2495-2504

Wehner J, Antunes PM, Powell JR, Mazukatow J, Rillig MC (2010) Plant pathogen protection by mycorrhizas: diversity takes central role. Pedobiol., 53: 197-201

Wolfe BE, Rodgers VL, Stinson KA, Pringle A (2008) The invasive plant Alliaria petiolata (garlic mustard) inhibits ectomycorrhizal fungi in its introduced range. J Ecol 96:777-783

Zar JH (1984) Biostatistical analysis, $2^{\text {nd }}$ Ed. Englewood Cliffs, NJ, USA: Prentice-Hall Zhang Q, Yao LJ, Yang RY, Yang XY, Tang JJ, Chen X (2007) Potential allelopathic effects of an invasive species Solidago canadensis on the mycorrhizae of native plant species. Allelopath J 20:71-77 
618

619

620

621

622

623

624

625

626

627

628

629

630

631

632

633

634

635

636

637

638

639

640

641

642

643

644

645

646

Figure Legends:

Fig. 1 Experiment 1. a) Effect of A. petiolata and AM fungal inoculation on the average number of detected T-RFLP fragments (T-RFs) in field and sterilized field soil. Bars represent mean values ( \pm S.E.M.). G. intraradices inoculation treatments are abbreviated as NA (no G. intraradices inoculum added), $+\mathrm{CA}$ (addition of the Canadian $G$. intraradices isolate), $+\mathrm{CH}$ (addition of the Swiss $G$. intraradices isolate), and +Mix (addition of a 1:1 mixture of both isolates). b) Ordination diagram of principal components 1 and 2 (Axis 1 and Axis 2) obtained from distance-based redundancy analysis. The distance between symbols (each representing an individual sample) in the diagram approximates the dissimilarity of their T-RF composition measured by their Euclidean distance. Different symbols and shadings represent inoculation treatments and soil sterilization treatments, respectively (see subpanel in Figure). NA samples from sterilized soils were highly irregular due to unspecific primer binding and, are not shown. +/- A. petiolata samples are not marked differently because $A$. petiolata did not have a significant effect on T-RF composition. Numbers in parentheses indicate the amount of variance accounted for by each principal component axis.

Fig. 2 Experiment 1. Effect of A. petiolata and AM fungal inoculation on the percentage of $S$. vulgare root length colonized by a) arbuscules, b) vesicles and c) hyphae in field and sterilized field soil. Bars represent mean values ( \pm S.E.M.). Figure captions are as in Fig. 1a.

Fig. 3 Experiment 1. Effect of A. petiolata and AM fungal inoculation on total shoot dry weight a), and number of shoots b) of $S$. vulgare at harvest in field and sterilized field soil. Figure captions are as in Fig. 1a.

Fig. 4 Experiment 2. a) Effect of $A$. petiolata extract on extraradical hyphal densities after 99 days of growth and $b$ ) on the average number of days needed since the onset before attaining maximal hyphal growth. Mean values ( \pm S.E.M.) of the two isolates are represented. 